\title{
Needs Analysis on Values Education Programme for Preschool Students ${ }^{*}$
}

\author{
Derya Kayıran ${ }^{1}$, Birsen Bağçeci ${ }^{2}$ \\ ${ }^{1}$ Kahramanmaras Sutcu Imam University, School of Vocational Services, Department of Child Care Programme, \\ Kahramanmaras, Turkey \\ ${ }^{2}$ Gaziantep University, Institute of Educational Sciences, Gaziantep, Turkey \\ Correspondence: Derya Kayıran, Kahramanmaras Sutcu Imam University, School of Vocational Services, Department \\ of Child Care Programme, Room Number 112, Bahcelievler, Kahramanmaras, Turkey.
}

Received: June 5, 2018 Accepted: August 2, $2018 \quad$ Online Published: August 15, 2018

doi:10.11114/jets.v6i10.3538

URL: https://doi.org/10.11114/jets.v6i10.3538

\begin{abstract}
In recent years, there is a big debate among researchers, teachers and decision makers about what to include in early childhood values education in preschools in Turkey. The aim of the current study is to make a need analysis for values education programme for preschoolers. This study was conducted with 200 preschool teachers in one of urban cities of Turkey -Kahramanmaraş- during 2016-2017 Spring semester. A values checklist is created for the current study by making use of Turkish Ministry of Education's 'Values Education Prescript'. The values checklist is a 5-Likert type scale coded as: Not important, Slightly important, Moderately important, Important, Very important. The teachers participated in this study were asked to rank values according to their self regard on importance of them. Findings of this study are analyzed by SPSS 22.0 Programme. According to the findings of the need analysis, top ten values which are chosen by teachers as essential to be implemented in preschools as part of the values education programme for preschoolers are as follows: Honesty, patriotism, responsibility, respect, respect to the elders, respect to environment, love, being fair, respect to others' rights and being modest. Also, least five values which were ranked by teachers are social responsibility, generosity, collaboration, forehandedness and courage.
\end{abstract}

Keywords: values, values education, preschool education, curriculum and instruction

\section{Introduction}

The most considerable qualification of people could be cited as their sociability.People define and find their identity within the society they live in. Social life requires some rules and surrounds people with its life styling rituals (Yalar, 2010). At this point, it could be said that rules and life rituals which are accepted by most of the society could be called as values. It is believed that people constitute his moral provision under the thumb of society's values (Bradshaw, Healey \& Smith, 2001).

Education is regarded as one of the most significant tools of socialization. Moreover, raising children as virtuous and equipped with values is believed as the most important goal of education (Cevizci, 2016).

Values are important for various disciplines, especially psychology, sociology and philosophy (Fitcher, 2006) and people were trying to define values from the point of their scientific view. Values firstly are introduced as a social concept by Znaniecki (cited in Aydın, 2011). They are not only regarded as an important concept but values are also cited as a problematic issue in social sciences due to its close relation with human behavior. Especially when it is thought in educational environment it might be an indispensable concept to adjust people to the society in which they live (Dilmaç \& Ekşi, 2007). According to Schwartz and Bilsky (cited in Kağıtçıbaşı \& Kuşdil 2000; Kurtulan, 2007) values are simply understood as beliefs and behavioral patterns which penetrate and affect our life.

Values and Early Childhood Education

Basically, values have common and universal features in essence. However, education, culture and experiences have an effect on development of values in an individual level (Uyanık Balat \& Dağal, 2006). And also educational settings are

\footnotetext{
*This study was generated from the Doctoral Thesis which was carried out by Derya Kayıran (Keskinpalta) with the advisement of Associate Professor Birsen Bağçeci.
} 
regarded as control mechanism centres where values, norms, behaviours and attitudes are being gained and monitored in children and teenagers (Erden, 1998). Educational settings have a big role to enhance development of values in children that are gained initially in family (Hökelekli \& Gündüz, 2007). As stated by Grieshaber and McArdle (2014), “early childhood institutions as places of identity construction where through play and activities, children engage in the formation of ethical identities".Ekşi (2003) stated that one of the most important roles of schools is to raise students who are academically successful and adorned with basic values. Children get very first knowledge about values in their early ages (Uyanık Balat \& Dağal, 2006). That's why early childhood education is very important to shape values development of children. Enhancing positive attitudes in children is easy in these ages. The purpose of preschool education is to teach children positive manners such as love, friendship and self-expression as well. All of these kinds of positive attitudes will promote better friendship and relation with others (Priest, 2007). Furthermore, it is believed that early positive experiences are useful for future life in human life (Gunnar \& Barr, 1998). These early experiences are fed from different sources like families, culture and schools. Especially teachers have a significant role in transmitting values to young individuals in schools.

From this point of view, values have been gaining extensive importance in recent years. Especially when technical and social aims began to rival moral virtues; values have started to get a huge importance in educational programmes in the world (Ampel, 2002). For instance, in Turkey, values remain dormant for decades; but there was a big revolution about values in 2010-2011 educational year. Ministry of education have decided to make values applicable in schools to support moral development of students. During the past educational years, -in 2011, 2012, 2013 and 2014- values were changed. As it could be seen here, although there is an assented injunction on values education; stillthere is no formal values education programmes for preschool students in Turkey. This study will be a basis for filling the gap in this situation and provide a baseline to develop an values education programme for preschool children.

People should take four elements into account in the decision process of the values for educational programmes. These four elements are; individual, society, relations and environment (Kinnier, Kernes \& Dautheribes, 2000). Currentresearch is a kind of need analysis for values education programme for preschool students. Democratic Approach was used for Needs Analysis. Democratic Approach is one of the sorts of Needs Analysis; it provides to have an idea on opinions of dominant people on determined subjectin a society (Demirel, 2014).In this study, it is aimed to get an opinion with making an attempt at outlining the views of preschool teachers on which values should be included in preschool curriculum studies as a kind of need analysis.

\section{Method}

\subsection{The Research Model}

In this survey design research, it was aimed to see current situation about the view of the teachers on values importance array.

\subsection{Participants}

In present study, participiants were randomly selected. Theyare consist of 169 women and 39 men. The individuals who were selected to participate were preschool teachers who were working in Kahramanmaraş at Spring semester of 2016/2017 academic year.These participiants were used because of their school area.

\subsection{Measurement Instrument}

Data have been collected with value ranking form which is prepared by the researcher in regard of Ministy of Education's 'Values Education Prescript'. Preschool teachers were asked to rank values on the self perception of themselves about importance array of values which were determined by Municipality of Education. The form consists of 29 values. Ranking scores listed based on their arithmetic means.

\section{Results}

In this study answers were calculated as percentages (\%) as well as $\mathrm{n}$ values (n). Table 1 shows ranking list of values. 
Table 1. Descriptive statistics on teachers' value ranking

\begin{tabular}{|c|c|c|c|c|c|c|}
\hline Values & $\begin{array}{l}\text { Not } \\
\text { important } \\
\text { n(\%) }\end{array}$ & $\begin{array}{l}\text { Low-grade } \\
\text { important n(\%) }\end{array}$ & $\begin{array}{l}\text { Medium-grade } \\
\text { important n(\%) }\end{array}$ & $\begin{array}{l}\text { Important } \\
\text { n(\%) }\end{array}$ & $\begin{array}{l}\text { Very } \\
\text { Importantn( }(\%)\end{array}$ & Total \\
\hline Honesty & - & $2(1.0)$ & $8(4.0)$ & - & 190(95.0) & $200(100.0)$ \\
\hline Responsibility & - & - & $3(1.5)$ & $24(12.0)$ & 173(86.5) & $200(100.0)$ \\
\hline Empathy & $3(1.5)$ & $1(0.5)$ & $7(3.5)$ & $45(22.5)$ & $144(72.0)$ & $200(100.0)$ \\
\hline Being fair & - & $2(1.0)$ & $2(1.0)$ & $33(16.5)$ & $163(81.5)$ & $200(100.0)$ \\
\hline Respect & - & $7(3.5)$ & $3(1.5)$ & $19(9.5)$ & $171(85.5)$ & $200(100.0)$ \\
\hline Self respect & - & $2(1.0)$ & $4(2.0)$ & $42(21.0)$ & $152(76.0)$ & $200(100.0)$ \\
\hline $\begin{array}{l}\text { Respect } \\
\text { environment }\end{array}$ & $1(0.5)$ & $3(1.5)$ & $4(2.0)$ & $27(13.5)$ & $165(82.5)$ & $200(100.0)$ \\
\hline Respect to elders & - & $7(3.5)$ & $3(1.5)$ & $19(9.5)$ & $171(85.5)$ & $200(100.0)$ \\
\hline $\begin{array}{ll}\text { Respect } & \text { to } \\
\text { differences } & \end{array}$ & - & - & $11(5.5)$ & $52(26.0)$ & $137(68.5)$ & $200(100.0)$ \\
\hline $\begin{array}{l}\text { Respect to others' } \\
\text { rights }\end{array}$ & - & - & $8(4.0)$ & $31(15.5)$ & $161(80.5)$ & $200(100.0)$ \\
\hline Self control & - & - & $7(3.5)$ & $39(19.5)$ & $154(77.0)$ & $200(100.0)$ \\
\hline Love & - & - & $6(3.0)$ & $30(15.0)$ & $164(82.0)$ & $200(100.0)$ \\
\hline Courage & $4(2.0)$ & $2(1.0)$ & $10(5.0)$ & $74(37.0)$ & $110(55.0)$ & $200(100.0)$ \\
\hline $\begin{array}{l}\text { Observance of } \\
\text { rules }\end{array}$ & & $5(2.5)$ & $2(1.0)$ & $52(26.0)$ & $141(70.5)$ & $200(100.0)$ \\
\hline Being modest & - & $4(2.0)$ & $16(8.0)$ & $39(19.5)$ & $141(70.5)$ & $200(100.0)$ \\
\hline Being confidential & $6(3.0)$ & $2(1.0)$ & $2(1.0)$ & $30(15.0)$ & $160(80.0)$ & $200(100.0)$ \\
\hline $\begin{array}{l}\text { Social } \\
\text { responsibility }\end{array}$ & - & $6(3.0)$ & $9(4.5)$ & $58(29.0)$ & $127(63.5)$ & $200(100.0)$ \\
\hline Generosity & - & $6(3.0)$ & $8(4.0)$ & $63(31.5)$ & $123(61.5)$ & $200(100.0)$ \\
\hline Sharing & - & $4(2.0)$ & $6(3.0)$ & $49(24.5)$ & $141(70.5)$ & $200(100.0)$ \\
\hline Forehandedness & - & $3(1.5)$ & $14(7.0)$ & $66(33.0)$ & $117(58.5)$ & $200(100.0)$ \\
\hline Patience & - & $4(2.0)$ & $10(5.0)$ & $48(24.0)$ & $138(69.0)$ & $200(100.0)$ \\
\hline Kindness & - & & $13(6.5)$ & $47(23.5)$ & $140(70.0)$ & $200(100.0)$ \\
\hline Optimism & - & $2(1.0)$ & $7(3.5)$ & $53(26.5)$ & $138(69.0)$ & $200(100.0)$ \\
\hline Being determined & $4(2.0)$ & $1(0.5)$ & $8(4.0)$ & $50(25.0)$ & $137(68.5)$ & $200(100.0)$ \\
\hline Collaboration & - & $4(2.0)$ & $12(6.0)$ & $65(32.5)$ & $119(59.5)$ & $200(100.0)$ \\
\hline Helpfulness & - & $3(1.5)$ & $6(3.0)$ & $43(21.5)$ & $148(74.0)$ & $200(100.0)$ \\
\hline Being tolerant & - & $3(1.5)$ & $8(4.0)$ & $43(21.5)$ & $146(73.0)$ & $200(100.0)$ \\
\hline $\begin{array}{l}\text { Being } \\
\text { compassionate }\end{array}$ & - & $3(1.5)$ & $6(3.0)$ & $30(15.0)$ & $161(80.5)$ & $200(100.0)$ \\
\hline Friendship & $4(2.0)$ & $1(0.5)$ & $6(3.0)$ & $39(19.5)$ & $150(75.0)$ & $200(100.0)$ \\
\hline Patriotism & - & - & $8(4.0)$ & $12(6.0)$ & $180(90.0)$ & $200(100.0)$ \\
\hline
\end{tabular}

Preschool teachers ranking list for need analysis for values education programme for preschool studentsis seen in Table 1. Teachers list top five values in an order of importance. According to findings, top ten values which are chosen by teachers are as follows: Honesty $(95.0 \%)$, patriotism(90.0\%), responsibility $(86.5 \%)$, respect $(85.5 \%)$, respect to the elders $(85.5 \%)$, respect to environment $(82.5 \%)$, love $(82.0 \%)$, being fair(81.5\%), respect to others' rights $(80.5 \%)$ and being modest $(70.5 \%)$. On the other hand, least five values which were ranked by teachers are social responsibility (63.5\%), generosity(61.5\%), collaboration(59.5\%), forehandedness(58.5\%) and courage(55.0).

\section{Discussion}

In the light of the findings which are get through this study allow researchers to show these conclusions: Teachers of preschool students are asked to list values in an order of their self perception of importance array of values for a need analysis of values education programme for preschool students. The most important top ten values are honesty, patriotism, responsibility, respect, respect to the elders, respect to environment, love, being fair, respect to others' rights and being modest; and alsoleast five values which were ranked by teachers are social responsibility, generosity, collaboration, forehandedness and courageaccording to the findings.

Value tendencies might differ from people to people. It might be very hard to find common judgement on this issue. Similar findings of various research support the data of this study.

Uzun ve Köse (2017) conducted a study about implementation of values in early childhood education. In their study, researchers get that teachers want their students to acquire these values: Respect, love, honesty, responsibility, patriotism, courage and helpfullness.

Sezer (2016) conducted a study in 2016. It was asked from parents of gifted students to mention the moral, national and universal values which are important for them. Moral values that are regarded as important by parents are honesty, respect, love, compassion, justice, fairness, sacrifice, charity and courage; National values are: love of country and 
nation, respect for national values and commitment, showing respect for individuals usefulness for the motherland, usefulness of the homeland and the nation, national unity and solidarity, protect the values of the republic, adhering to the principles of Ataturk, protecting the interests of the country and efficient use of resources; and the universal values are: contribute to universal peace, human love, respect for human rights, commitment to the values of humanity, universal friendship, universal tolerance, protection and contribution of the world cultural heritage, protection and contribution to science heritage of the world, protecting the natural environment and respect for diversity.

The another study which was implemented by Yiğittir (2010) found that parents are more willing to see the following values on their children: emphasis on family unity, courage, faithfulness, industriousness, success, trustworthiness, forgiveness and patriotism.

Saglam (2016) made a comprehensive study in 2016.In one part of his study, he asked parents to list values regarding their self perception on priority of values. It was found that parents want to see these values on their children: living in unity and peace, fairness, trustworthiness and empathy.

Tay (2009) questioned the views of prospective social sciences teachers' regarding the importance level of values. The researcher sought out to determine the top and least five values that were being incorporated and the prospective teachers' perceptions on importance level of them. According to the study, prospective teachers list values as follows: top five values are: respect, love, patriotism, honesty, morality and being fair and tolerance. And also they attach least importance to being economical, cleanliness, historical empathy, love for the national flag, Ataturkism and democracy respectively.

On the other hand, Yazıcı (2006) claim that students should gain not only cultural values but also they should gain universal values in this globalizing world.

In the light of above research examples, it could be said that results of current study compatible with other studies in the literature. Moreover, current study shows that teachers pay too much attention to respect related values. For instance they rank respect, respect to the elders, respect to environment and respect to others'rights in top ten values. On the other hand, responsibility, generosity, collaboration, forehandedness and courage values ranked as least five values by teachers, this situation need more attention to be interpreted.

As a conclusion; values are regarded as hidden goals in curricula until the revision in Turkish National Curricula 2004. Then with this revision values are mentioned directly and take part in school activities. However, in 2017 the school programme revision studies are started again. This time values are thought to be put directly in curricula. However, there is no formal curriculum programme for values education yet. Especially in preschool education, there is a big gapin this issue, because humanbeing' learning performance is too fast in early ages and it is also believed that knowledge which are thought in early years of human life would be more permanent than any other ages in the future. From the point of this view; it might be said that values education curricula is very urgent need for preschools. And also it is believed that findings of this need analysis study might shed light the future studies on values education programmes for preschools which will take place in the future.

\section{References}

Ampel, J. (2009). Character education: Examining the perceptions of elementary, middle, and high school teachers in a central Florida schooldistrict. Electronic Theses and Dissertations Paper 3885. University of Central Florida, Florida.

Aydın, M. (2011). Values, functions and morality. Glance of Education Journal,7(19), 39-45.

Bradshaw, Y., Healey, J. F., \& Smith, R. (2001). Sociologyfor a newcentury. Boston: PineForgePress.

Cevizci, A. (2016). Philosophy of Education. İstanbul: Say Pub.

Demirel, Ö. (2014). Curriculum Development From Theory to Practice. Ankara: Pegem Pub.

Dilmaç, B., \& Ekşi, H. (2007). Values Education: Basic Approaches. İlköğretmen Journal, 14, 21-29.

Ekşi, H. (2003). An approach to bring values: Character education Programmes. Journal of Values Education, 1(1), 79-96.

Erden, M. (1998). Introduction to be teacher. Istanbul: Alkım Pub.

Fichter, J. (2006). What is Sociology? (Interpreter: Nilgün Çelebi). Ankara: AnıPub.

Grieshaber, S., \& McArdle, F. (2014). Ethical dimensions and perspectives on play. InL. Brooker, M. Balise. https://doi.org/10.4135/9781473907850.n11

Gunnar, M. R., \& Barr, R. G. (1998). Stress, early brain development, andbehavior. InfantsandYoungChildren, 11(1), $1-14$. 
Hökelekli, H., \& Gündüz, G. (2007). Value tendency and education of special children.International Values Education Symposium, DEM Publishing, 371-396.

Kağıtçıbaşı, Ç., \& Kuşdil, E. (2000). Value tendencies of turkish teachers. Turkish Psychology Journal, 15, 56-76.

Kinnier, R. T., Kernes, J. L., \& Dautheribes, T. M. (2000). A shortlist of universal moral values. CounselingandValues, 45(1), 4-17.

Kurtulan, I. (2007). Self evaluaton of special education teachers on job ethics. Unpublished Masters Thesis, Marmara Institute of Educational Sciences, İstanbul.

Priest, C. (2007). Incorporating character education into the early childhood degree program: The need, and one department's response. Journal of Early Childhood Teacher Education, 28(2), 153-161. https://doi.org/10.1080/10901020701366723

Sağlam, A. (2016). Views of parents about impact of values education on student behaviours. Turkish Social Sciences Studies Journal, 3, 723-742.

Sezer, A., \& Çoban, O. (2016). Perception of responsibility value by students.Uşak University Education Studies Journal, 2(1), 23-39.

Tay, B., Durmaz, F., \& Şanal, M. (2013). Views of students on values and values education in social sciences lecture.Gazi Education Department Journal, 33(1), 67-93.

Uyanık-Balat, G., \& Dağal, A. B. (2006). Activities on values education in preschools. Ankara: Kök Pub.

Uzun, M., \& Köse, A. (2017). Implications of teachers on implementation of values education in preschool level. Bayburt Education Department Journal, 12(23), 305-338.

Yalar, T. (2010). Determining the current situation of values education in primary school social studies curriculum by teachers opinions, Unpublished Doctoral Thesis, Mersin University, Institute of Social Sciences, Mersin.

Yazıc1, K. (2006). General view on values education. Turkish Sciences Studies, 19(19), 499.

Yiğittir, S. (2010). Preferred values by parents in primary level of schools. Values Education Journal, 8(19), 207-223.

\section{Copyrights}

Copyright for this article is retained by the author(s), with first publication rights granted to the journal.

This is an open-access article distributed under the terms and conditions of the Creative Commons Attribution license which permits unrestricted use, distribution, and reproduction in any medium, provided the original work is properly cited. 